\title{
Penanaman Hidroponik dan Olahannya Sebagai Pencegahan Berat Badan Kurang di Desa Cibitung Wetan, Pamijahan, Bogor
}

\section{(Hydroponic Cultivation and Processing for Underweight Prevention in Cibitung Wetan Village, Pamijahan, Bogor)}

\author{
Heny Agustin ${ }^{*}$, Indri Indrawan ${ }^{2}$ \\ 1 Program Studi Agroekoteknologi, Fakultas Bioindustri, Universitas Trilogi, Jln. TMP Kalibata No 1, RT 04/04, Duren Tiga, \\ Kecamatan Pancoran, Jakarta, 12760. \\ 2 Program Studi Ilmu dan Teknologi Pangan, Fakultas Bioindustri, Universitas Trilogi, Jln. TMP Kalibata No 1, RT 04/04, \\ Duren Tiga, Kecamatan Pancoran, Jakarta, 12760. \\ *Penulis Korespondensi: henyagustin@trilogi.ac.id \\ Diterima November 2020/Disetujui September 2021
}

\begin{abstract}
ABSTRAK
Universitas Trilogi bersama kelompok Kampung Ramah Lingkungan (KRL) Seroja Kahuripan melaksanakan pengabdian terkait pencegahan berat badan kurang di Desa Cibitung Wetan, Pamijahan, Bogor. Kegiatan ini bertujuan untuk mengedukasi pentingnya pangan bergizi melalui hidroponik dengan pelatihan pembuatan greenhouse, instalasi hidroponik, pelatihan budi daya tanaman sayur serta olahannya untuk meningkatkan nilai tambah pangan sebagai bentuk pencegahan berat badan kurang. Metode pelaksanaan kegiatan melalui beberapa tahap yaitu: 1) Tahap persiapan dan koordinasi; 2) Tahap pelaksanaan; dan 3) Tahap monitoring dan evaluasi. Berdasarkan data yang diperoleh, diketahui 13,69\% anak berusia 0-23 bulan menderita berat badan kurang dengan berat badan jauh di bawah standar dan 34,44\% anak mendekati berat badan kurang. Upaya pencegahan berat badan kurang dilakukan dengan menguatkan identitas mitra, melakukan pembangunan greenhouse dan instalasi hidroponik serta pelatihan budi daya tanaman sayur oleh tim agar mitra dapat mandiri dalam penyediaan pangan bergizi. Hasil panen berupa sayuran kemudian diolah menjadi nugget dan dendeng agar memberikan nilai tambah gizi kepada mitra. Hasil dari kegiatan ini adalah bertambahnya jumlah anggota mitra dari 15 menjadi 54 orang, terbentuknya logo sebagai penguat identitas kelompok, terbangunnya fasilitas greenhouse dan rangkaian instalasi hidroponik, meningkatnya pengetahuan dan keterampilan mitra terhadap budi daya hidroponik hingga cara mengolah hasil panennya, serta meningkatnya kepedulian mitra terhadap isu berat badan kurang. Hasil angket kepuasan mitra menunjukkan $85 \%$ menyatakan sangat puas terhadap program yang dilakukan dan berharap dapat terus dibina untuk selanjutnya.
\end{abstract}

Kata kunci: berat badan kurang, greenhouse, hidroponik, tanaman sayur

\begin{abstract}
Trilogi University with the community 'Kampung Ramah Lingkungan' (KRL) Seroja Kahuripan have conducted underweight prevention services in Cibitung Wetan Village, Pamijahan, Bogor. This service activity aims to educate importance of nutritious food, train in creating greenhouses and hydroponic installations, cultivate vegetable crops and their processing to increase the food value as prevention of underweight. The method was carried out in several stages: 1) The preparation and coordination; 2) Implementation; and 3) monitoring and evaluation. Based on the data, it was known that $13,69 \%$ of children aged $0-23$ months are observed with underweight with body weight far below the standard and $34,44 \%$ of children are approaching as underweight. Efforts to prevent underweight were carried out by strengthening the identity of partners, the construction of greenhouse and hydroponic installation as well as training in vegetable cultivation carried out by the team so that partners can be independent in providing nutritious food. The yields of vegetables and their processed products in form of nuggets and jerky have provided food value added increasement to partners. As a result, increasement in the number of partner members from 15 to 54 people, the formation of a group logo as identity reinforcement, the construction of greenhouse facilities and hydroponic installations series, increasement of partner's knowledges and skills in hydroponic cultivation and crops processing, and increasement partner's awareness of underweight issue. The results of partner's satisfaction questionnaire showed that $85 \%$ were very satisfied with the program and they hoped for sustainable and further fostering.
\end{abstract}

Keywords: greenhouse; hydroponics; underweight, vegetable crops 


\section{PENDAHULUAN}

Persoalan berat badan kurang pada balita di Indonesia menjadi perhatian banyak pihak selain stunting dan wasting. Istiah berat badan kurang atau underweight merupakan suatu keadaan anak balita yang mengalami gizi kurang atau gizi buruk (SK Menkes No.1995/Menkes/SK/XII/ 2010). Berdasarkan hasil pemantauan status gizi Kementrian Kesehatan (2018) diketahui bahwa persentase underweight/berat badan kurang/ gizi kurang (gizi buruk ditambah gizi kurang) pada kelompok anak usia 24-59 bulan di Indonesia sebesar 17,8\%, lebih tinggi dibandingkan kelompok anak usia 0-23 bulan sebesar $14,8 \%$.

Bogor termasuk wilayah yang status gizi balita dengan berat badan kurang tercatat sebesar $15,2 \%$ dengan karakteristik masalah gizi masuk pada kategori kronis. Persentase tersebut lebih tinggi dibandingkan rata-rata nilai status gizi balita di Provinsi Jawa Barat, yaitu 15,1\% (Kemenkes 2018). Menanggapi hal tersebut, Universitas Trilogi sebagai perguruan tinggi yang telah bekerja sama dengan Pemerintah Daerah Kabupaten Bogor, khususnya Kecamatan Pamijahan sejak tahun 2018 perlu mengambil sikap dan ambil bagian dalam penyelesaian masalah ini sebagai bentuk pengabdian kepada masyarakat.

Berawal dari program kemitraan yang dilakukan tahun 2019, khususnya tentang penanganan permasalahan sampah melalui pengembangan bank sampah terkomputerisasi (Agustin et al. 2020) menghasilkan gagasan bahwa uang kas nasabah yang ada di kelompok bank sampah tersebut kemudian diputar dan dipergunakan untuk operasional penghijauan melalui sistem tanam hidroponik. Hasil budi dayanya diolah sedemikian rupa untuk dijadikan olahan pangan bergizi dalam rangka pencegahan berat badan kurang di Desa Cibitung Wetan. Hal ini juga dapat menjadi salah satu promosi untuk meningkatkan jumlah nasabah bank sampah yang tidak hanya mendapatkan manfaat dari tabungan bank sampah yang dikumpulkannya, melainkan juga mendapat hasil panen budi daya tanaman serta olahan pangan untuk peningkatan gizi keluarga.

Mitra kelompok masyarakat adalah Kampung Ramah Lingkungan (KRL) khususnya divisi penghijauan Seroja Kahuripan yang telah terintegrasi dengan tim bank sampah setempat, yang pada praktiknya telah melakukan kolaborasi dengan memanfaatkan sampah organik sebagai media tanam untuk penghijauan khususnya penanaman tanaman sayur. Kegiatan budi daya tanaman yang saat itu berjalan masih konvensional sehingga perlu adanya inovasi teknologi melalui metode tanam lain seperti hidroponik. Penanaman dengan hidoroponik diklaim lebih baik dalam segi kesehatan dibandingkan dengan cara konvensional. Hal ini senada dengan penelitian yang dipublikasikan oleh Jurnal Practical Hydroponics \& Greenhouses tahun 2000 yang menunjukkan bahwa tanaman hidroponik lebih unggul dalam segi gizi dan rasanya dibandingkan tanaman konvensional Hellosehat (2017).

Pilihan komoditas tanaman yang menjadi bahan utama budi daya juga penting karena hasilnya akan diolah dalam bentuk panganan yang disukai khususnya oleh anak-anak dalam proses pemenuhan gizinya. Komoditas tanaman sayur seperti kale, bayam, kangkung, pakcoy, dan caisim menjadi pilihan untuk budi daya secara hidroponik. Hal ini juga dipilih karena beberapa pertimbangan, seperti benihnya yang mudah diperoleh, cara pemeliharaan yang cenderung lebih mudah serta siklus penanamannya yang cukup singkat. Berdasarkan keseluruhan komoditas yang ditanam, tanaman sayur kale menjadi perhatian khusus kelompok. Kale dianggap paling sesuai dengan analisis kebutuhan yang dimaksud karena merupakan tanaman sayur yang kaya akan gizi dengan kandungan vitamin A, C, K, kalium, kalsium, zat besi, dan mangan. Kandungan vitamin $\mathrm{C}$ pada kale hijau mencapai 152,18 mg/100 g dan kale ungu mencapai 182,3 mg/100 g (Agustin \& Ichniarsyah 2018). Dalam $50 \mathrm{~g}$ daun kale segar, terdapat kurang lebih 0,7 g lemak, 10 g karbohidrat, 3,3 g protein, serat, dan mineral penting seperti natrium dan kalium yang dapat menyumbangkan 2\% dari Angka Kecukupan Gizi (AKG) berdasar diet harian $2.000 \mathrm{kkal}$ (Permenkes 2019).

Kegiatan pengabdian ini bertujuan untuk mengedukasi pentingnya pangan bergizi melalui pendekatan hidroponik dengan pelatihan pembuatan greenhouse, instalasi hidroponik, pelatihan budi daya tanaman sayur serta olahannya untuk peningkatan nilai tambah pangan sebagai bentuk pencegahan berat badan kurang. Pembuatan produk olahan terpilih seperti nugget maupun dendeng dari panen sayuran dilakukan dengan mempertimbangkan kelompok usia target dan preferensi jenis pangan olahan yang dapat diterima secara umum. Harapannya, melalui gerakan penanaman budi daya tanaman sayur melalui metode hidroponik mampu menjadi salah satu bentuk alternatif dan 
sumbangan keilmuan Universitas Trilogi untuk Desa Cibitung Wetan dalam rangka pencegahan berat badan kurang.

\section{METODE PELAKSANAAN KEGIATAN}

\section{Waktu, Tempat, dan Partisipan Kegiatan}

Program kemitraan masyarakat dilakukan pada Februari-Oktober 2020 di Desa Cibitung Wetan, Kecamatan Pamijahan, Kabupaten Bogor, Jawa Barat. Kelompok mitra yang bekerja sama adalah masyarakat non ekonomi atau sosial yang bergerak di bidang penghijauan lingkungan hidup. Kelompok ini tergabung dengan nama Kampung Ramah Lingkungan (KRL) Seroja Kahuripan. Adapun target sasaran program kemitraan ini adalah ibu hamil, ibu menyusui, serta ibu yang memiliki balita dan anak-anak yang wajib terdaftar sebagai anggota KRL Seroja Kahuripan (mitra).

\section{Bahan dan Alat}

Bahan yang digunakan adalah baja ringan, paranet, talang air, tutup talang, corong talang, pipa 1 inci, tee 1 inci, keni 1 inci, pipa 1 1/4 inci, stop keran, rockwool, lem PVC, semen, pasir, benih kale, benih bayam, benih kangkung, benih caisim, benih pakcoy, pupuk $\mathrm{AB} m i x$, aluminium foil, kertas roti, tepung terigu, tepung roti, bumbu-bumbu, daging ayam, minyak goreng, plastik kemasan, dan stiker. Sedangkan alat yang digunakan ialah alat tulis, gergaji, bor, cangkul, ember, mata bor, gunting, sekop, cutter, hole, gerinda, pompa air, mesin air, selang, baskom, kuas silikon, loyang, mangkok, sodet, talenan, wajan, kukusan, kompor, blender, tabung gas, sealer, food processor dan timbangan digital.

\section{Metode Pelaksanaan}

Metode pelaksanaan kegiatan program kemitraan masyarakat ini terbagi atas beberapa tahap. Secara garis besar ada tiga tahapan penting, yaitu: 1) Tahap persiapan dan koordinasi terhadap kebutuhan mitra; 2) Tahap pelaksanaan berupa pelatihan secara langsung; dan 3) Tahap monitoring dan evaluasi.

\section{- Tahap persiapan dan koordinasi}

Tahap persiapan dilakukan oleh tim untuk berkoordinasi dengan seluruh anggota pengurus mitra serta aparat desa dengan cara duduk bersama dalam rangka mendiskusikan mengenai langkah-langkah kegiatan yang dilakukan. Pendataan terhadap target sasaran dilakukan melalui bantuan kader posyandu yang berada di setiap RW. Keluarga yang memiliki anak usia 023 bulan melakukan proses penimbangan secara terjadwal ke posyandu, kemudian hasil data timbangannya dikumpulkan ke puskemas pembantu yang berada di tingkat desa untuk dilaporkan dan dihitung datanya sebagai gambaran kasus berat badan kurang di desa mitra. Hasil pendataan selanjutnya ditindaklanjuti oleh tim pelaksana pengabdian dengan melakukan wawancara kepada para ibu yang anaknya masuk pada ketegori berat badan kurang atau yang mendekati.

\section{- Tahap implementasi}

Tahap implementasi dilakukan tim pelaksana pengabdian dengan melakukan pembangunan greenhouse. Tahapan ini diawali dengan survei dan pengukuran lahan seluas $48 \mathrm{~m}^{2}$ di lokasi yang menjadi calon kebun hidroponik. Lokasi ini merupakan lahan kosong yang tidak terpakai, milik dari salah satu anggota keluarga pengurus mitra yang peruntukkannya telah disetujui untuk kepentingan kelompok. Greenhouse dibangun dengan rangka baja ringan dan paranet dengan ukuran tiang setinggi $4 \mathrm{~m}$ sebagai pertukaran udara serta mobilisasi kegiatan saat proses penanaman berlangsung. Tahapan penunjang lainnya yang juga dilakukan adalah penggalian sumur tanah sedalam $4 \mathrm{~m}$ sebagai sumber air dalam budi daya hidroponik. Hal ini dilakukan karena lokasi kebun cukup jauh dari pemukiman. Penggalian sumur menjadi bagian yang sangat penting, karena kekuatan hidroponik terletak pada sumber air yang bersih dengan $\mathrm{pH}$ yang sesuai.

Tahapan implementasi selanjutnya adalah perakitan instalasi hidroponik dengan menggunakan talang air yang dimodifikasi sepanjang $4 \mathrm{~m}$ dengan pondasi dudukan menggunakan baja ringan yang ditanam ke dalam tanah menggunakan semen. Area instalasi hidroponik ini terbagi atas satu area persemaian/peremajaan dan dua area pembesaran/produksi. Seluruh instalasi hidroponik yang dibuat mengadopsi model nutrient film technique (NFT) yang lapisan nutrisinya dangkal dengan kemiringan tertentu.

Pelatihan budi daya tanaman dilakukan setelah greenhouse dan instalasi hidroponik siap digunakan. Tim pelaksana pengabdian melakukan pelatihan budi daya tanaman sayur terhadap mitra KRL Seroja Kahuripan. Komoditas yang ditanam adalah kale, bayam, kangkung, caisim, dan pakcoy. Pelatihan tahap awal dilakukan dengan proses penyemaian benih 
dengan menggunakan media tanam rockwool yang telah dipotong $2 \times 2 \mathrm{~cm}$ dengan satu be $\mathrm{nih}$ untuk setiap satu rockwool pada tanaman kale, pakcoy, caisim atau 5-7 benih untuk setiap satu rockwool pada tanaman kangkung maupun bayam.

Benih yang telah berkecambah kemudian dipindahkan ke area peremajaan setelah setidaknya memiliki 2-3 helai daun. Tanaman kale membutuhkan waktu sekitar 4-5 hari sampai bibit memiliki 2-3 helai daun, sementara untuk tanaman lainnya, tim memberikan catatan waktu berkecambah kepada mitra untuk mempermudah pelaksanaan budi daya. Bibit tanaman yang telah berada di area peremajaan ditunggu selama satu minggu untuk mendapatkan asupan hara awal dan kemudian dipindahkan ke area produksi setelahnya sampai siap panen. Cara kerja atau SOP dalam budi daya tanaman dengan sistem hidroponik sangat krusial.

Mitra perlu mengetahui beberapa hal penting, di antaranya: kriteria benih yang memiliki viabilitas atau daya berkecambah yang tinggi (tampak pada informasi di label kemasan benih), konsentrasi larutan pupuk di setiap umur tanaman, cara mengontrol $\mathrm{pH}$ larutan serta operasional pengairan dalam pemeliharaan tanaman. Saat tahap inilah, konsentrasi air dan hara pupuk sudah diperhatikan sehingga penting sekali untuk mengukur konsentrasi ppm pupuk dan $\mathrm{pH}$ nutrisi yang sesuai.

Waktu yang dibutuhkan dalam budi daya hidroponik bervariasi, sesuai dengan jenis komoditi yang ditanam. Kisarannya mencapai 3050 hari setelah tanam. Tanaman yang paling cepat dipanen adalah kangkung dan bayam, sedang yang paling lama adalah kale. Oleh karena itu, pengaturan jadwal tanam dilakukan agar setidaknya setiap dua minggu sekali dapat dipanen secara bergilir. Hasil panen dari budi daya hidroponik yang dipanen kemudian diolah dengan cara demonstrasi langsung (praktik memasak) di depan mitra. Pilihan olahan yang dibuat adalah nugget dan dendeng sayur, terutama yang berasal dari komoditas tanaman sayur kale.

Proses pembuatan nugget kale dilakukan dengan menghaluskan daging ayam dan daun kale yang telah diblansir sebelumnya dengan menggunakan food processor. Bahan yang telah halus kemudian ditambahkan terigu yang telah diberi sejumlah bumbu dan air untuk menjadi adonan yang selanjutnya dimasukkan ke dalam loyang selama 30-40 menit untuk dikukus. Setelah pengukusan, adonan yang telah dingin dipotong-potong sesuai kreasi dan dipanir dengan putih telur serta tepung roti untuk selanjutnya digoreng. Proses pembuatan dendeng kale dilakukan dengan cara mengukus daun kale selama 1015 menit, peras airnya hingga habis, setelah itu dicincang hingga halus. Daun kale yang telah dicincang kemudian dicampur bumbu (bawang putih, kencur, ketumbar, kaldu sapi, garam, dan gula) dan bahan lain (telur ayam, lengkuas parut, tepung, gula, garam, dan penyedap) untuk kemudian dikukus selama 15-20 menit. Hasil kukusan didinginkan, potong tipis-tipis, dipipihkan dengan dipukulpukul kemudian dikeringkan lalu digoreng.

\section{- Tahapan monitoring dan evaluasi}

Tahapan ini dilakukan secara simultan pada setiap bagian kegiatan yang dilakukan. Evaluasi program dilakukan dengan cara membagikan angket kepuasan kepada mitra setelah mengikuti program kemitraan masyarakat yang dilakukan oleh tim pelaksana pengabdian selama kurun waktu delapan bulan. Atribut yang ditanyakan terkait dengan materi pelatihan (kejelasan dan hubungan materi dengan kebutuhan), cara instruktur/narasumber membawakan materi (teknik penyajian dan waktu pemaparan) serta sejauh mana manfaat materi kepada mitra (respons mitra dan minat mitra dalam mengikuti kegiatan) dengan skala kepuasan 1-5 (5 sangat puas, 4 puas, 3 cukup puas, 2 kurang puas, dan 1 sangat kurang puas). Seluruh data tersebut ditabulasi dengan menggunakan Ms. Excel, kemudian dirata-ratakan dan dibuat dalam bentuk persentase. Sementara itu, indikator berupa perubahan kondisi sebelum dan sesudah kegiatan pengabdian dilakukan, dicermati melalui pengamatan langsung/observasi secara berkala selama kurun waktu pengabdian untuk melihat sejauh mana output yang dihasilkan.

\section{HASIL DAN PEMBAHASAN}

\section{Tahap Persiapan dan Koordinasi}

Tahap persiapan dan koordinasi dilakukan sebagai langkah awal antara tim pelaksana pengabdian dengan mitra serta aparat Desa Cibitung Wetan, Pamijahan, Bogor. Pertemuan koordinasi ini penting dilakukan agar tim dan mitra saling mengetahui antara kebutuhan dan program yang dijalankan, sehingga dapat terjalin kesepakatan bersama. Hal ini dilakukan sebagai bentuk komitmen desa terhadap dukungan kelancaran pengabdian yang dilakukan oleh tim 
selama kurun waktu delapan bulan. Hasil lainnya yang juga dilakukan adalah dengan menguatkan identitas kelompok mitra yang telah terbentuk melalui pembuatan logo. Logo ini selanjutnya dapat dicantumkan dalam spanduk maupun berbagai produk yang dihasilkan oleh kelompok mitra (Gambar 1).

Tim pelaksana pengabdian selanjutnya melakukan koordinasi dengan kader posyandu dan puskemas pembantu desa setempat untuk memperoleh data jumlah anak yang mengalami berat badan kurang atau yang mendekati. Indikator berat badan anak hingga usia dua tahun menjadi parameter utama karena penurunan berat badan secara terus menerus dan serius merupakan salah satu indikasi gizi buruk. Hasil pendataan menunjukkan bahwa ada sebanyak $13,69 \%$ anak usia $0-23$ bulan yang mengalami berat badan kurang, sebanyak 34,44\% yang mendekati berat badan kurang, dan sisanya sebanyak 51,87\% dinyatakan sehat dengan berat badan sesuai dengan tumbuh kembang anak (Tabel 1).

Berdasarkan data perolehan diketahui bahwa Desa Cibitung Wetan sebetulnya cukup rawan dengan kondisi gizi buruk, meskipun data persentase jumlah anak yang mengalami berat badan kurang di bawah rata-rata nasional yang telah mencapai $14,8 \%$ akan tetapi jika sejumlah anak yang telah mendekati berat badan kurang tidak tertangani maka jumlahnya akan meningkat hingga 29,04\%. Angka ini tentu menjadi gambaran serius terkait permasalahan berat badan kurang di Desa Cibitung Wetan.

Hasil penelitian mengenai gizi di Kabupaten Bogor khususnya dengan indikator berat badan telah dilakukan sejak lama. Menurut Permaesih et al. (2000) tingkat persentase underweight di Kabupaten Bogor tahun 2000 menunjukkan angka 4,4\%. Hasil tersebut meningkat tajam pada tahun 2017 yang mencapai 15,2\% berdasarkan hasil pemantauan masalah dan kinerja program gizi di Provinsi Jawa Barat yang dilakukan oleh Kementrian Kesehatan. Peningkatan yang sangat besar tersebut diharapkan menjadi perhatian serius bagi Pemerintah Kabupaten Bogor, sehingga dapat segera tertangani.

Data jumlah anak dengan berat badan kurang tersebut kemudian diverifikasi oleh tim pelaksana dengan melakukan proses wawancara mendalam kepada beberapa orang tua khususnya para ibu yang anaknya mengalami berat badan kurang (Gambar 2). Hasil wawancara menunjukkan bahwa faktor utama penyebab berat badan kurang adalah minimnya pengetahuan

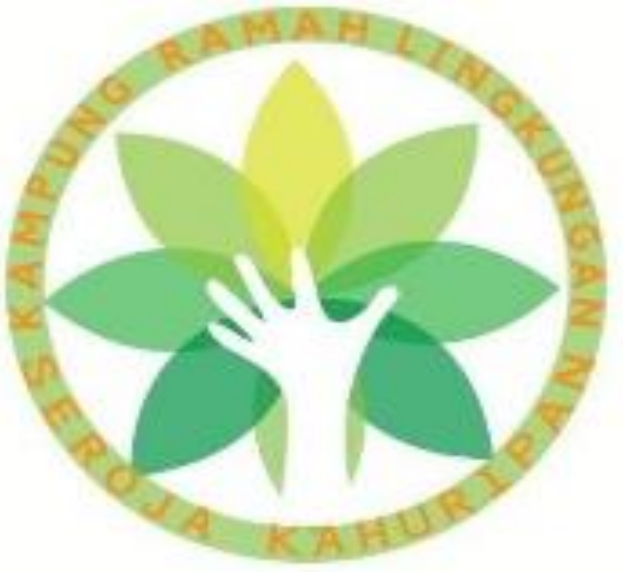

Gambar 1 Logo mitra kampung ramah lingkungan Seroja Kahuripan.

Tabel 1 Data berat badan anak usia 0-23 bulan di Desa Cibitung Wetan

\begin{tabular}{lc}
\hline \multicolumn{3}{c}{ Keterangan } & Jumlah \\
\hline Jumlah anak $0-23$ bulan yang berat & 33 \\
badannya di bawah garis merah & \\
Jumlah anak $0-23$ bulan yang berat & 37 \\
badannya masuk ke garis merah & \\
Jumlah anak $0-23$ bulan yang berat & 46 \\
badannya masuk ke garis kuning & \\
Jumlah anak $0-23$ bulan yang berat & 125 \\
badannya masuk ke garis hijau normal & \\
Total & 241 \\
\hline
\end{tabular}

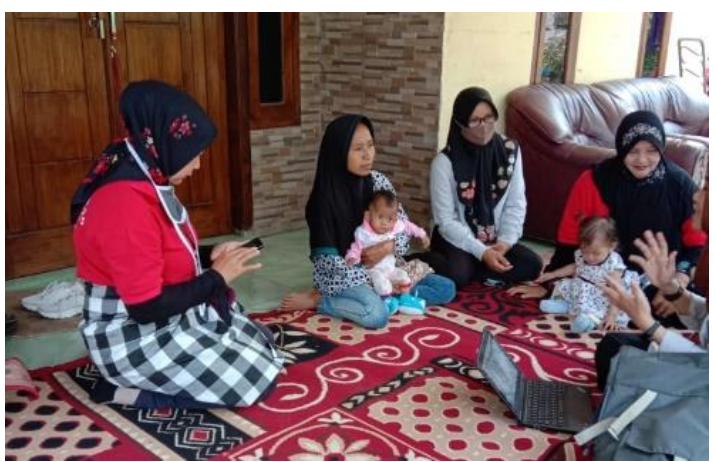

Gambar 2 Proses wawancara dengan orang tua yang memiliki anak dengan berat badan kurang.

orang tua terhadap tumbuh kembang anak serta masalah asupan gizi dari ibu yang masih menyusui akibat ekonomi keluarga yang buruk. Menurut Pujiastuti (2016) ada korelasi antara gizi ibu yang buruk dengan produksi (kecukupan) ASI yang dihasilkan.

Permasalahan berat badan kurang pada anak disebabkan karena 50\% ibu hamil di lokasi mitra enggan memeriksakan kandungannya ke sarana kesehatan yang sebetulnya tidak berbayar/ gratis. Hal ini tidak disadari oleh para ibu jika dampaknya dapat berakibat pada kesehatan anak yang akan dilahirkan. Hal tersebut selaras 
dengan hasil penelitian Karima \& Achadi (2012) yang menyatakan bahwa intervensi terbaik untuk mencapai berat badan lahir bayi yang ideal dapat dilakukan dengan mempersiapkan status gizi prahamil ibu, karena ibu dengan berat badan prahamil kurang dari $50 \mathrm{~kg}$ berisiko 6,64 kali lebih besar untuk melahirkan bayi dengan berat badan lahir kurang dari $3000 \mathrm{~g}$. Hal ini juga diperkuat oleh Ruindungan et al. (2017) yang menyatakan bahwa adanya hubungan antara pemeriksaan kandungan dengan kejadian berat badan lahir rendah. Setelah dikonfirmasi, ibu hamil di lokasi mitra tidak punya cukup waktu untuk berkunjung ke sarana kesehatan karena sangat sibuk mengurus anak-anak lainnya. Hal ini tidak terlepas dari jumlah anak yang banyak dalam keluarga sehingga tidak adanya prioritas.

\section{Tahap Implementasi}

Pembangunan kebun hidroponik dilakukan di atas lahan kosong milik dari salah satu anggota keluarga kelompok mitra. Lahan kosong tersebut dipinjamkan dengan sistem tanpa biaya sewa dan sengaja diperuntukkan untuk kepentingan kelompok. Hal ini membuat tim dan mitra tidak kesulitan dalam proses pembangunan karena tidak ada silang sengketa pada lahan yang digunakan. Lahan ini juga berdekatan dengan area posko bank sampah, yang mana kedua kelompok ini saling terhubung dan keberadaanya menguatkan satu sama lain.

Terbangunnya greenhouse seluas $48 \mathrm{~m}^{2}$ dengan konstruksi baja ringan dan paranet serta instalasi hidroponik dengan menggunakan talang air modifikasi di area lokasi mitra diharapkan menjadi fasilitas yang dapat digunakan dan dimanfaatkan hasil panen maupun olahannya dalam peningkatan gizi pangan bagi sasaran mitra. Masuknya inovasi hidroponik ke desa masih menjadi hal yang sangat baru dan mampu

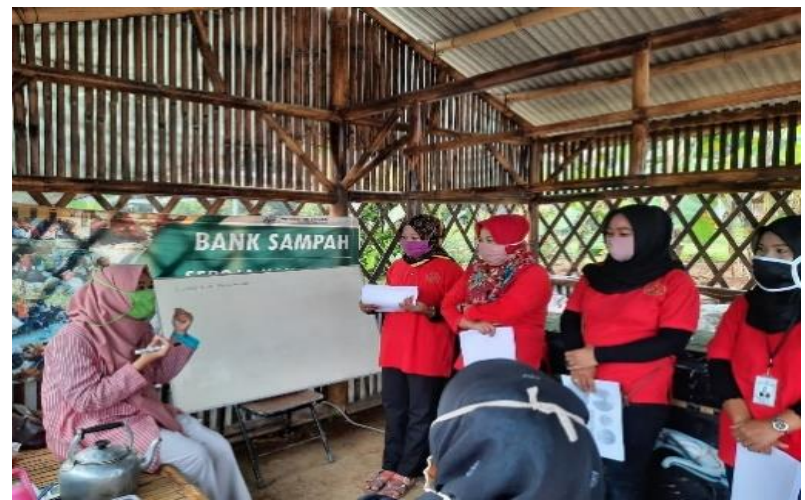

a memberikan banyak manfaat. Menurut Roidah (2014) teknik hidroponik dapat memelihara lebih banyak tanaman dalam satuan ruang yang lebih sempit dan sistem ini harus bebas pestisida, sehingga tidak ada serangan hama dan penyakit. Suryathi \& Resiani (2017) menyatakan bahwa hidroponik merupakan konsep pertanian berkelanjutan yang meski dengan skala rumah tangga (non industri) mampu memberikan penghasilan tambahan. Gashgari et al. (2018) menyatakan bahwa sistem tanam dengan hidroponik memberikan pengaruh terhadap produktivitas tanaman dibandingkan sistem konvensional.

Tim selanjutnya melakukan sosialisasi tentang hidroponik, perbedaan dengan sistem tanam konvensional, pengenalan dengan media tanam non tanah (rockwool), penggunaan nutrisi pupuk $A B$ mix hingga perawatan dan pemeliharaan instalasi hidroponik. Dilanjutkan dengan pelatihan menanam di rockwool hingga benih bisa dipindah setelah memenuhi kriteria hingga dapat dipanen (Gambar 3 dan 4). Proses pelatihan oleh tim dilakukan beberapa kali sampai mitra mampu melakukan metode budi daya tanam tanpa tanah secara mandiri dengan tetap didampingi secara berkala.

Hasil panen hidroponik selanjutnya digunakan sebagai bahan baku untuk diolah kembali menjadi panganan bergizi. Pelatihan demo masak dilakukan oleh tim secara langsung bersama mitra untuk mengolah komoditas sayur kale yang telah dipanen menjadi nugget dan dendeng (Gambar 5 dan 6). Pelaksanaan demo masak juga sekaligus merupakan sarana edukasi tim kepada mitra tentang pentingnya pangan bergizi dari aspek pengolahan pangan yang benar. Kedua olahan tersebut dipilih karena disukai oleh ibuibu dan anak-anak sehingga lebih mudah untuk diterima target sasaran. Panen segar maupun olahannya ini dapat dimanfaatkan oleh masya-

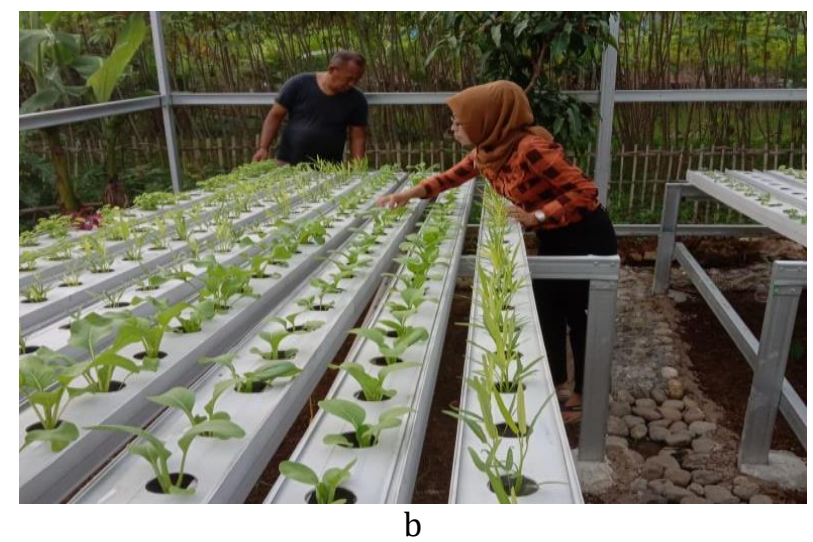

b

Gambar 3 a dan b Proses pelatihan budi daya hidroponik ke mitra. 


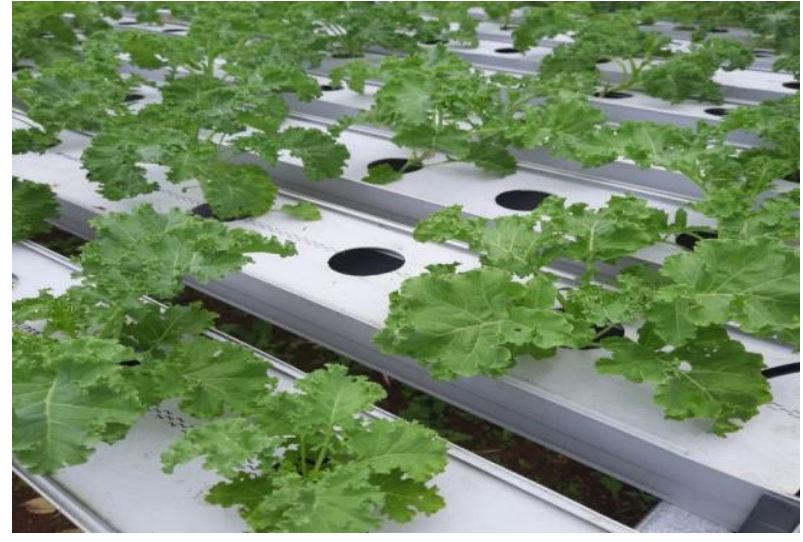

Gambar 4 Tanaman sayur dengan hidroponik yang sudah siap panen.

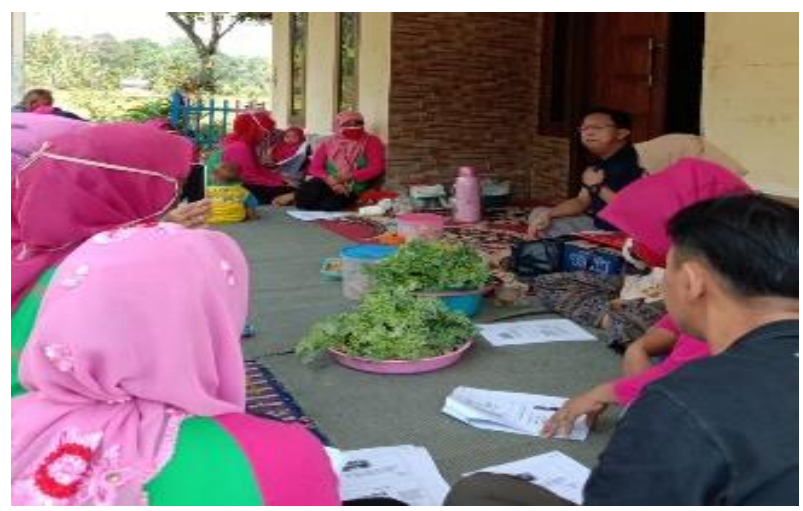

Gambar 5 Kegiatan pelatihan demo masak hasil panen hidroponik menjadi olahan nugget dan dendeng kale.
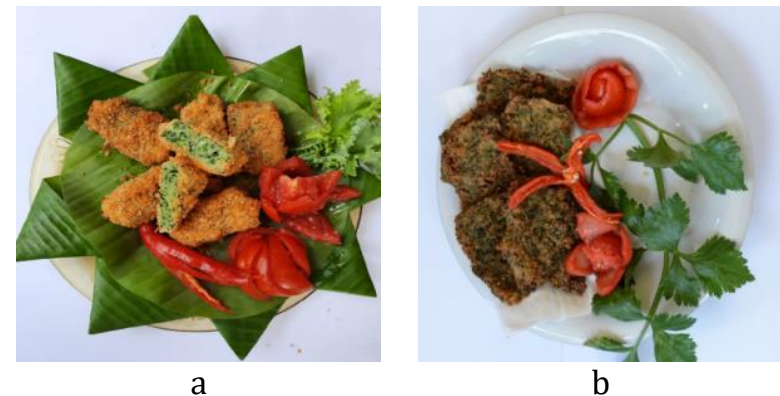

b

Gambar 6 Hasil olahan sayur (kale) dari hidroponik menjadi kudapan a) nugget dan b) dendeng.

rakat desa (khususnya mereka yang menjadi target sasaran) dengan cara menjadi anggota kelompok mitra KRL Seroja Kahuripan.

Langkah pencegahan melalui budi daya tanaman sayur dengan metode hidroponik tentu tidak bisa langsung mengatasi permasalahan berat badan kurang yang terjadi di lokasi mitra. Hal ini terkait dengan kandungan gizi pada sayur yang utamanya mengandung vitamin bukan kandungan protein. Oleh karena itu, dalam pembuatan nugget kale, tetap dibutuhkan bahan tambahan berupa daging ayam sebagai asupan proteinnya. Protein hewani ditambahkan karena mampu membentuk water holding capacity (WHC) sehingga menghasilkan produk yang lebih baik karena dapat mengikat protein (Van Laack 1999). Selain itu, menurut Jati \& Nindya (2017) terdapat hubungan asupan energi dan protein terhadap kejadian underweight pada bayi di bawah usia dua tahun sehingga perlu peningkatan konsumsi pangan yang bergizi dari segi kualitas maupun kuantitas.

Berdasarkan hal tersebut, tim berupaya untuk mengintegrasikan hidroponik yang telah terbangun dengan budi daya ikan lele di lokasi mitra untuk keberlanjutan program selanjutnya. Lele dinilai menjadi komoditas ikan berprotein tinggi yang cukup mudah diadaptasi dan juga telah banyak diusahakan di Desa Cibitung Wetan. Menurut Hasanah \& Fitriani (2020) produk nugget kombinasi lele dan mocaf dapat dijadikan alternatif kudapan tinggi protein bagi balita.

\section{Tahapan Monitoring dan Evaluasi}

Program kegiatan gerakan penanaman melalui hidroponik ini memberikan banyak manfaat bagi kelompok mitra. Tindakan preventif ini tentu tidak dapat menyelesaikan permasalahan berat badan kurang secara langsung apalagi cepat, maka diperlukan kooordinasi dan kekompakan mitra di dalamnya. Mitra wajib mengajak target sasaran (ibu hamil, ibu menyusui, dan ibu dengan balita) untuk menjadi anggota mitra KRL Seroja Kahuripan agar dapat mengakses hasil panen hidroponik maupun olahannya untuk dikonsumsi sebagai panganan bergizi bagi keluarga.

Hasil pengamatan di lapangan menunjukkan beberapa perubahan ke arah positif (Tabel 2). Hal ini tentu saja berdampak baik bagi mitra, apalagi jika terus dirawat dan dipelihara sehingga persoalan berat badan kurang yang dialami oleh warga di Desa Cibitung Wetan dapat terselesaikan sedikit demi sedikit. Hasil angket kuesioner menunjukkan bahwa 85\% anggota mitra KRL Seroja Kahuripan sangat puas terhadap seluruh program yang dilakukan oleh tim pelaksana pengabdian Universitas Trilogi (Gambar 7). Mereka berharap dapat terus dibina agar lebih baik kedepannya. Lokasi mitra yang merupakan satu dari delapan desa binaan Universitas Trilogi memang menjadi prioritas dalam program pengabdian kepada masyarakat. Tim berharap dapat terus membina kelompok sehingga hasil riset dosen dapat dihilirisasi dan bermanfaat bagi masyarakat banyak.

Secara umum seluruh kegiatan pengabdian berjalan dengan lancar. Mitra KRL Seroja 
Tabel 2 Perubahan yang terjadi dalam mitra sebelum dan setelah proses pelaksanaan pengabdian dilakukan.

\begin{tabular}{|c|c|c|}
\hline Indikator & $\begin{array}{l}\text { Kondisi sebelum pelaksanaan } \\
\text { pengabdian }\end{array}$ & $\begin{array}{c}\text { Kondisi setelah pelaksanaan } \\
\text { pengabdian }\end{array}$ \\
\hline Jumlah anggota pada mitra & Jumlah anggota 15 orang & Jumlah anggota menjadi 54 orang \\
\hline Identitas mitra & Belum memiliki logo & Kelompok telah memiliki logo \\
\hline $\begin{array}{l}\text { Sarana hidroponik (greenhouse } \\
\text { dan instalasi) }\end{array}$ & Tidak ada & $\begin{array}{l}\text { Terbangunnya satu unit green } \\
\text { house dan rangkaian instalasi } \\
\text { hidroponik }\end{array}$ \\
\hline $\begin{array}{l}\text { Pengetahuan dan keterampilan } \\
\text { mitra terhadap budi daya } \\
\text { hidroponik }\end{array}$ & $\begin{array}{l}\text { Pengetahuan dan keterampilan } \\
\text { mitra masih terbatas pada budi } \\
\text { daya tanam secara konvensional }\end{array}$ & $\begin{array}{l}\text { Pengetahuan dan keterampilan } \\
\text { mitra bertambah dengan adanya } \\
\text { inovasi budi daya tanam tanpa } \\
\text { tanah secara hidroponik }\end{array}$ \\
\hline $\begin{array}{l}\text { Pengetahuan dan keterampilan } \\
\text { mitra terhadap olahan hasil } \\
\text { panen hidroponik }\end{array}$ & $\begin{array}{l}\text { Mitra belum tahu cara mengolah } \\
\text { tanaman khususnya sayur kale } \\
\text { menjadi olahan bergizi yang disukai } \\
\text { anak-anak }\end{array}$ & $\begin{array}{l}\text { Mitra memperoleh tambahan } \\
\text { pengetahuan cara mengolah } \\
\text { khususnya tanaman sayur kale } \\
\text { menjadi panganan bergizi yang } \\
\text { disukai anak-anak }\end{array}$ \\
\hline $\begin{array}{l}\text { Pengetahuan tentang stunting } \\
\text { secara umum }\end{array}$ & $\begin{array}{l}\text { Mitra belum peduli dan lebih pada } \\
\text { acuh terhadap stunting karena } \\
\text { tidak mengetahui bahayanya }\end{array}$ & $\begin{array}{l}\text { Mitra lebih peduli terhadap } \\
\text { stunting dan meminimalisir untuk } \\
\text { pencegahannya }\end{array}$ \\
\hline
\end{tabular}

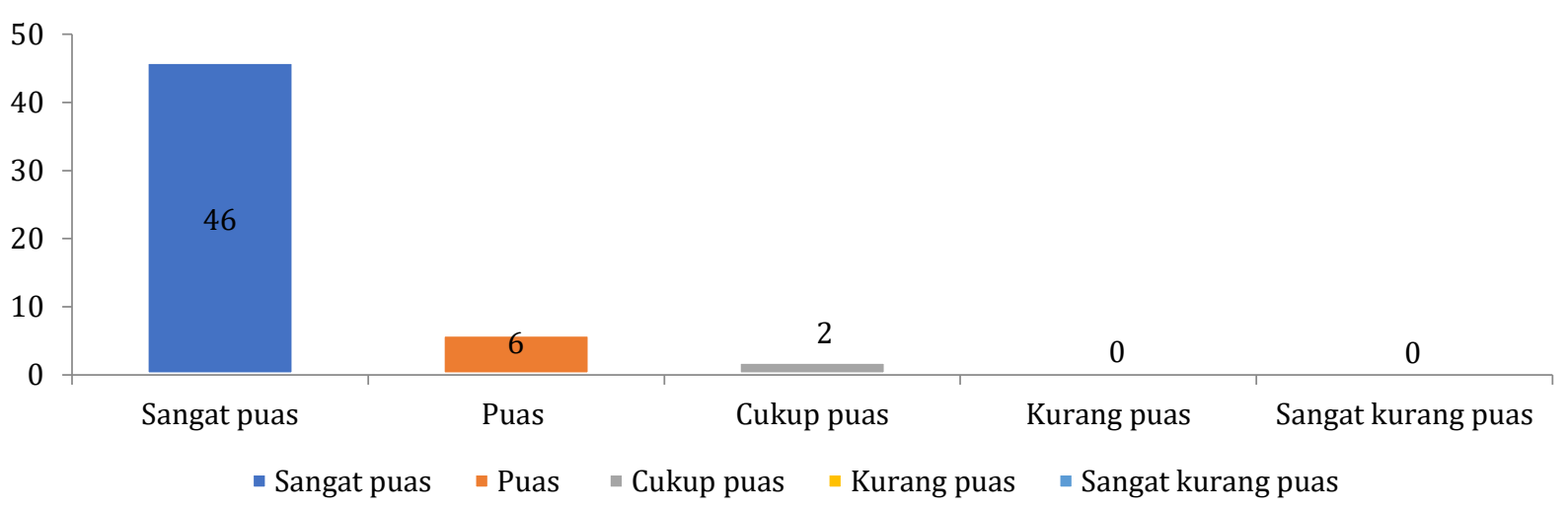

Gambar 7 Persentase tingkat kepuasan mitra terhadap seluruh rangkaian program tim pelaksana di lokasi mitra.

Kahuripan sangat kooperatif dalam program pengabdian ini. Pada umumnya kendala terjadi karena pengabdian dilakukan saat pandemi covid-19 yang melanda Indonesia. Asal lokasi tim pelaksana yang berada di Jakarta (zona merah) cukup menyulitkan karena kekhawatiran terhadap kesehatan. Kondisi ini sebetulnya tidak mudah bagi tim dalam menyelesaikan program yang telah direncanakan sejak 2019.

Kendala sinyal di lokasi mitra menyulitkan koordinasi tim. Oleh kerena itu, pertemuan virtual dengan aplikasi zoom saat itu tidak memungkinkan dilakukan dan komunikasi via telepon dan whatsapp menjadi alternatifnya. Sampai bulan Juni 2020, mitra dengan bantuan dana desa memasang wifi di kantor desa sehingga memudahkan koordinasi dan komunikasi selanjutnya. Pengerjaan program di lapang dilakukan saat new normal diberlakukan, yaitu sejak bulan Juni 2020. Saat itu tim langsung bergerak cepat untuk turun ke lapang dengan tetap mentaati protokol kesehatan, seperti memakai masker, menjaga jarak dan membatasi jumlah anggota saat pertemuan maupun pelatihan.

\section{SIMPULAN}

Hasil pendataan di Desa Cibitung Wetan menunjukkan sebanyak 13,69\% anak di usia 023 bulan mengalami berat badan kurang dan sebanyak 34,44\% mendekati berat badan kurang. Upaya mengedukasi pentingnya pangan bergizi melalui hidroponik yang dilakukan oleh tim berdampak pada perubahan kelompok mitra di antaranya pertambahan jumlah anggota dari 15 menjadi 54 orang dalam kelompok, terbentuknya logo identitas kelompok, terbangunnya fasilitas greenhouse dan rangkaian instalasi hidroponik, meningkatnya pengetahuan dan keterampilan mitra terhadap budi daya hidroponik hingga cara pengolahan hasil panennya, serta meningkatnya 
kepedulian mitra terhadap isu berat badan kurang. Hasil angket menunjukkan sebanyak 85\% mitra sangat puas terhadap program yang dilakukan oleh tim pengabdian dan berharap terus dibina untuk selanjutnya.

Rekomendasi kegiatan pengabdian lanjutan yang dapat dilakukan di lokasi mitra dalam rangka pencegahan berat badan kurang, yaitu dengan mengintegrasikan pertanian terpadu antara hidroponik yang fasilitasnya telah terbangun dengan budi daya lele sebagai asupan protein sehingga kebutuhan nutrisi pangan anak dapat lebih optimal.

\section{UCAPAN TERIMA KASIH}

Tim pelaksana pengabdian mengucapkan terima kasih kepada seluruh pihak terutama Kemenristek/BRIN yang telah mendanai program ini melalui hibah Program Kemitraan Masyarakat tahun anggaran 2020. Tim juga mengucapkan banyak terima kasih kepada Kepala Desa Cibitung Wetan, Kecamatan Pamijahan, Kabupaten Bogor beserta jajarannya yang telah menyukseskan program ini.

\section{DAFTAR PUSTAKA}

Agustin H, Ichniarsyah AN. 2018. Efektivitas KNO3 terhadap pertumbuhan dan kandungan vitamin C kale. Jurnal Agrin. 22(1): 46-55. https://doi.org/10.20884/1.agrin.2018.22.1. 458

Agustin H, Setiawan R, Puspitasari AK. 2020. Pengembangan bank sampah terkomputerisasi di Desa Cibitung Wetan Bogor.Jurnal Kumawula. 3(2): 140-153. https: //doi.org/10.24198/kumawula.v3i2.24771

Gashgari R, Alharbi K, Mughrbil K, Jan A, Glolam A. 2018. Comparison between growing plants in hydroponic system and soil based system. In: Proceedings of the 4th World Congress on Mechanical, Chemical, and Material Engineering (MCM'18). Madrid, Spain: Paper No. ICMIE 131. https://doi.org/ 10.11159/icmie18.131

Hasanah LN \& Fitriani RJ. 2020. Daya terima dan kandungan gizi naget lele (Clarias gariepinus) dengan susbtitusi modified cassava flour (mocaf) sebagai alternatif kudapan tinggi protein untuk balita. Jurnal 2-TRIK: Tunas-
Tunas Riset Kesehatan. 10(2): 80-85.

Hellosehat. 2017. Apakah Tanaman Hidroponik Lebih Sehat dari Sayur Biasa? [Internet]. [diunduh 24 Agustus 2019]. Terdapat pada: https://hellosehat.com/hidup-sehat/faktaunik/apakah-sayuran-hidroponik-lebihsehat/.

Jati DK, Nindya TS. 2017. Asupan energi dan protein berhubungan dengan gizi kurang pada anak usia 6-24 bulan. Amerta Nutrition. 124132.

https://doi.org/10.20473/amnt.v1i2.6234.

Karima K, Achadi EL. 2012. Status gizi ibu dan berat badan lahir bayi. Jurnal Kesehatan Masyarakat Nasional. 7(3): 111-119. https://doi.org/10.21109/kesmas.v7i3.57

Kementrian Kesehatan. 2018. Buku Saku Pemantauan Status Gizi (PSG) 2017. [Internet]. [diunduh 30 Agustus 2021]. Terdapat pada: https://kesmas.kemkes.go.id/ assets/uploads/contents/others/Buku-SakuNasional-PSG-2017_975.pdf.

Peraturan Menteri Kesehatan Republik Indonesia No 28 Tahun 2019. 2019. [Internet]. [diunduh 30 Agustus 2021]. Terdapat pada: https://peraturan.bpk.go.id/ Home/Details/138621/permenkes-no-28tahun-2019.

Permaesih D, Rosmalina Y, Christijani R, Martuti S, Herman S. 2000. Status gizi balita di Kabupaten Bogor pada krisis ekonomi. Penelitian Gizi dan Makanan. 23: 18-24.

Pujiastuti N. 2016. Korelasi antara status gizi ibu menyusui dengan kecukupan asi di Posyandu Desa Karang Kedawang Kecamatan Sooko Kabupaten Mojokerto. Jurnal Keperawatan. 1(20): 126-137. https://doi.org/10.22219/ jk.v1i2.407

Roidah. 2014. Pemanfaatan lahan dengan menggunakan sistem hidroponik. Jurnal Universitas Tulungagung BONOROWO. 1(2): 43-49.

Ruindungan RY, Kundre R, Masi GNM. 2017. Hubungan pemeriksaan antenatal care (anc) dengan kejadian berat badan lahir rendah (bblr) di wilayah kerja RSUD Tobelo. Jurnal Keperawatan. 5(1): 1-8.

Surat Keputusan Menteri Kementrian Kesehatan. 2010. Keputusan Menteri Kesehatan Republik Indonesia Nomor 1995/Menkes/SK/XII/2010 
tentang standar antropometri penilaian status gizi anak. Jakarta: Direktorat Bina Gizi.

Suryathi NW, Resiani NMD. 2017. Increasing household revenues through hydroponic agricultural as sustainable agricultural efforts. Sustainable Environment Agricultural Science (SEAS). 1(2): 69-75. https://doi.org/10. 22225/seas.1.2.401.69-75

Van Laack RLJM. 1999. The Role of Proteins in Water-Holding Capacity of Meat. Department of Food Science and Technology University of Tennessee, Knoxville. Plenum Publishers, New York (UK). https://doi.org/10.1007/978-14615-4731-0_21 